\title{
Komunitas Kristiani sebagai Duta Kasih Allah di tengah Kebinekaan Bangsa Indonesia
}

\author{
Mathias Jebaru Adon ${ }^{1}$, Anton Sad Budi ${ }^{2}$ \\ 1,2Sekolah Tinggi Filsafat Teologi Widya Sasana, Malang \\ 1jmathiasjebaruadon@gmail.com, 2antonsad@gmail.com
}

\begin{abstract}
The focus of this research study describes the role of Christians in strengthening the spirit of diversity in the Indonesian nation. Currently, Indonesia is not only facing the Covid-19 pandemic but also a national identity crisis. In various places there are rampant intolerance, radicalism and acts of extremism-terrorism that threaten the integrity of the nation. In this situation Christians are called to show their identity by becoming ambassadors for God's love. By becoming ambassadors of God's love, Christians prove that love is greater than enmity. Christians can start by living together in community. In the community, Christians are trained to be more sensitive to the sufferings of the world and not run out of power. This research study uses a phenomenological approach which starts from the calling of Christians to live in a spirit of love. Because in the way of living together all differences are put together. Thus, the Christian community becomes a good platform for channeling love to others regardless of ethnicity, race and religion. Therefore, the Christian community is a means of realizing togetherness in a spirit of diversity.
\end{abstract}

Keywords: Christian community; diversity; Indonesian nation: ambassadors of God's love

\begin{abstract}
Abstrak: Fokus studi penelitian ini menguraikan peran orang Kristiani dalam memperkuat semangat kebinekaan Bangsa Indonesia. Saat ini Indonesia tidak hanya menghadapi pandemi covid-19 tetapi juga krisis identitas kebangsaan. Di berbagai tempat marak terjadi intoleransi, radikalisme dan tindakan ekstremisme-terorisme yang mengancam keutuhan bangsa. Berhadapan dengan situasi ini orang Kristiani dipanggil untuk menunjukkan identitasnya dengan menjadi duta kasih Allah. Dengan menjadi duta kasih Allah orang Kristiani membuktikan bahwa, kasih lebih besar dari permusuhan. Orang Kristiani dapat memulainya dengan hidup bersama dalam komunitas. Dalam komunitas, orang Kristiani dilatih untuk lebih peka mendengar penderitaan dunia dan tidak kehabisan daya. Studi penelitian ini menggunakan pendekatan fenomenologi yang bertitik tolak dari panggilan orang Kristiani untuk hidup dalam semangat kasih. Sebab dalam cara hidup bersama segala perbedaan disatukan. Dengan demikian komunitas Kristiani menjadi wadah yang baik untuk menyalurkan kasih kepada sesama tanpa memandang suku, ras dan agama. Karena itu, komunitas Kristiani adalah sarana untuk mewujudkan kebersamaan dalam semangat kebinekaan.
\end{abstract}

Kata kunci: duta kasih Allah; bangsa Indonesia; kebinekaan; komunitas Kristiani

\section{PENDAHULUAN}

Badai pandemi Covid-19 yang tengah menghantam dunia telah membawa dampak yang luar biasa. Badai ini bagaikan terowongan panjang setiap sektor. Di Indonesia situasi ini semakin suram karena marak terjadi politik identitas, intoleransi dan tindakan ekstremisme-terorisme. Bom bunuh diri yang terjadi di depan Gereja 
Katedral Makasar pada 28 Maret 2021 menjadi sinyal bagi seluruh pihak terutama pemerintah untuk tidak pernah kendor dalam melaksanakan protokol penanganan ekstremisme-kekerasan meski tengah menghadapi gempuran virus Corona. Hal ini menunjukkan bahwa meski Indonesia menjunjung tinggi semboyan Bhinneka Tunggal Ika sebagai identitas bangsa, namun hal tersebut tidak menjamin intoleransi, rasisme, dan radikalisme agama hilang. Karena itu pemerintah perlu melakukan tindakan komprehensif dan terukur dalam rangka memitigasi peristiwaperistiwa tersebut sehingga tidak mencederai rasa kemanusiaan dan semangat kebinekaan yang selama ini terus digalakkan oleh pemerintah dan masyarakat. Sebab situasi ini akan semakin kritis jika tidak ditangani dengan baik seperti pengalaman pahit yang pernah terjadi di Sambas, Kupang, Surabaya, Situbondo, Tasikmalaya dan berbagai tempat lainnya yang membahayakan kesatuan dan persatuan bangsa. ${ }^{1}$

Penanganan tersebut berkaitan dengan memperkokoh semangat kebinekaan dan meningkatkan semangat rela berkorban dari warga masyarakat, serta ketulusan dalam mengabdi bangsa dan negara. Hal ini penting mengingat isu-isu SARA dan identitas sektorian semakin digembar-gemborkan akhir-akhir ini, bahkan tidak jarang juga dikapitalisasi dan diinstrumentalisasi demi kepentingan politik. ${ }^{2}$ Saat ini polarisasi dan fragmentasi masyarakat dipertajam dengan maraknya gerakan radikalisme agama yang diringi oleh tindakan ekstremisme-terorisme yang mengatasnamakan kelompok dan agama tertentu. Pemerintah sendiri telah menunjukkan keseriusannya ketika Presiden Joko Widodo menandatangani Peraturan Presiden No 7 tahun 2021 tentang Rencana Aksi Nasional Pencegahan dan Penanggulangan Ekstremisme Berbasis Kekerasan yang Mengarah pada Terorisme (RAN-PE). ${ }^{3}$

Meski demikian masyarakat sipil memiliki peran yang tidak kalah penting untuk berkontribusi secara signifikan bagi pencegahan ekstremisme- kekerasan dengan memupus lingkungan pemicu melalui pembangunan masyarakat yang toleran dan inklusif. Hal ini mesti dibuktikan dengan keterlibatan aktif stakeholder yang ada dalam masyarakat, salah satunya lembaga religius. Sebab tidak dapat dipungkiri, salah satu motif tindakan terorisme global ialah melaksanakan keyakinan yang dipercayainya. Para pelaku yakin dengan meninggal di tempat saat melakukan tindakan serangan tergolong sebagai suatu tindakan mulia. ${ }^{4}$ Berdasarkan hal tersebut, Gereja sebagai salah satu lembaga religius dan stakeholder dalam masyarakat memainkan peran yang sangat penting untuk mendidik dan

${ }^{1}$ Arthur Aritonang, "Peran Sosiologis Gereja Dalam Relasi Kehidupan Antar Umat Beragama Indonesia," TE DEUM (Jurnal Teologi dan Pengembangan Pelayanan) 9, no. 1 (2019): 69-102.

2 I.B.G Yudha Triguna, "Kebhinekaan Bangsa Indonesia: Urgensi Dan Relevansinya Dalam Era Revolusi Industri 4.0," Dharmasmrti: Jurnal Ilmu Agama dan Kebudayaan 10, no. 2 (2019): 46-52.

3 Dimas Ryiandi and Muhammad Ridwan, "Bom Bunuh Diri Di Makassar, Ekstremisme Tetap Subur Meski Pandemi," Jawa Pos (Surabaya, 2021).

4 Rizky Suryarandika, “Menebak Motif Di Balik Bom Bunuh Diri Makassar,” Harian Aceh Indonesia. 
membimbing umatnya agar dapat hidup berdampingan secara damai di tengah perbedaan dan kebinekaan.

Gereja dapat memulainya dengan membudayakan semangat kasih di antara umatnya sebab kasih dapat menyentuh akar-akar kehidupan manusia yang paling dalam. Namun kasih yang dimaksud bukan sikap moralitas, yakni bagaimana orang Kristiani harus bersikap sebagai orang Kristiani yang baik, melainkan suatu cara berada dalam dunia yang baru yang dipenuhi cinta Kristus. Dimana orang Kristiani membuat belas kasih Allah yang tak terbatas menjadi nyata dan dapat disentuh (2Kor 5:20). Maka kasih yang ditunjukkan bukanlah satu keutamaan yang harus diambil kalau cara-cara lain untuk memberi tanggapan sudah tidak ada lagi melainkan satu cara berada dalam dunia yang baru yang dipenuhi cinta Kristus. Singkat kata belas kasih yang dimaksud bukan sekedar rasa kasihan secara sentimental (rasa iba) atau sebagai ikut rasa kasihan saja. Tetapi lebih berarti mendengarkan dalam "compassion" (ikut merasakan), kata "passion" (penderitaan). ${ }^{5}$ Hal ini berarti seruan untuk keadilan dan sekaligus memberi jawaban yang berupa keinginan kuat untuk menanggapi hubungan-hubungan tidak adil yang mengejutkan yang berada di dunia kita ini. Dengan kata lain hidup Kristiani adalah hidup yang menjadi saksi Allah yang berbelas-kasih. ${ }^{6}$ Melalui cara hidup ini orang Kristiani dapat merasakan penderitaan sesama dengan baik sehingga dengan cara demikian dapat memberikan kehidupan baru kepada orang lain. Secara khusus di tengah kehidupan bangsa Indonesia di mana hidup bersama dicabik-cabik oleh konflik, perang, kebencian dan intoleransi.

Disinyalir salah satu latar belakang tindakan radikalisme dan terorisme adalah sentimen keagamaan yang sudah tertanam kuat dan diwariskan secara teruntemurun di antara para penganutnya. Sentimen antara umat muslim dan kristen misalnya tidak terlepas dari sejarah kehadiran gereja-gereja zending pada zaman kolonialisme Belanda yang sikapnya terlalu terarah kepada eksklusivisme. Pada zaman itu, orang Kristen Belanda merasa superior atas orang Islam di Indonesia lewat aktivitas zending dan kegiatan kolonialisme Belanda. Akibatnya kekristenan mendapatkan labelisasi sebagai agama penjajah. ${ }^{7}$ Sebaliknya, saat ini umat muslim seringkali dilabelisasi sebagai umat yang patuh dan taat tetapi mengarah kepada terorisme. Berhadapan dengan sikap primordialisme ini, Gereja tidak dapat berbuat lain selain melawannya dengan menunjukkan persahabatan dan kasih yang tulus dengan semua orang, khususnya umat muslim. Sebab dengan kasih ketegangan dan jarak melebur sehingga suatu cakrawala baru akan muncul. Inilah tujuan hidup kristen yakni hidup dalam persahabatan yang bernafaskan kasih yang selalu mendorong orang untuk bersikap solider dengan sesama.

\footnotetext{
${ }^{5}$ Henri. J. M. Nouwen, Donald P. Mcneill, and Douglas A. Morrison, Sehati Seperasaan, ed. Willem. S. G. Pau (Yogyakarta: Kanisius, 1987).

${ }^{6}$ Henri J. M Nouwen, Kembalinya Si Anak Yang Hilang; Membangun Sikap Kebapaan Dan Keputraan (Yogyakarta: Kanisius, 1995). Indonesia."

${ }^{7}$ Aritonang, "Peran Sosiologis Gereja Dalam Relasi Kehidupan Antar Umat Beragama
} 
Namun perbuatan kasih itu tidak bernilai jika dilakukan sendiri-sendiri sebagai individu tetapi dalam kebersamaan, kebersamaan yang dimaksud adalah sosialitas. Sosialitas bukan berarti kebersamaan material badan seperti makan bersama atau duduk bersama tetapi perkara menjadi sesama bagi yang lain dan memandang yang lain menjadi sesamaku. ${ }^{8}$ Hal ini diwujudkan dengan hidup bersama dalam komunitas. Tetapi komunitas yang dimaksud bukan soal hidup bersama dalam satu rumah tetapi kebersamaan dalam sosialitas. Hidup bersama dalam sosialitas karenanya bukan kesamaan hobi, kesesuaian intelektual, daya tarik jasmani, kesamaan dalam cita-cita dan karena latar belakang budaya dan agama yang sama. Semua ini dapat menjadi unsur-unsur yang penting dalam hubungan yang baik, tetapi tidak memberi jaminan bagi hidup komunitas. ${ }^{9}$ Kualitas utama dari sebuah komunitas adalah keyakinan yang mendalam bahwa orang diper-satukan oleh Allah.

Kebersamaan kasih yang demikianlah yang menjadi ciri khas kasih Kristiani. Karena di dalam komunitas seseorang dilatih untuk memberikan kemerdekaan, kepercayaan, dan peneguhan kepada sesama. Di dalamnya orang Kristiani saling menghormati dengan saling mendengarkan dalam semangat saling percaya dimana setiap orang mati terhadap diri sendiri, sehingga orang lain dapat hidup, berkembang dan menjadi anugerah. Karena itu dalam komunitas Kristiani setiap orang berkumpul dalam Nama Kristus, perasaan dan pikirannya diubah menjadi perasaan dan pikiran Kristus yang tidak asing dengan penderitaan dunia. Dalam komunitas ini ketakutan dan kemarahan diubah oleh kasih Allah yang tanpa batas. Dengan demikian hidup kita menjadi hidup yang berbelas-kasih karena dalam cara kita hidup dan bekerja sama, belas kasih Allah hadir di tengah dunia yang hancur. Di sini arti hidup yang berbelas-kasih menyatakan diri secara lebih dalam.

Karena itu, tulisan ini pertama-tama menguraikan peran Gereja sebagai salah satu lembaga religius dalam menciptakan masyarakat yang toleran yang didasarkan pada belas kasih Allah. Kedua, bagaimana orang Kristiani dipanggil untuk bersaksi menjadi duta kasih Allah di tengah kebhinnekaan manusia Indonesia. Ketiga, dalam melaksanakan tugas dan panggilannya ini orang Kristiani tidak dapat melakukannya sendiri sebagai individu tetapi dalam kesatuan dengan komunitas Kristiani. Dalam komunitas ini orang Kristiani belajar menguatkan dan mendengarkan satu sama lain, sehingga cara hidup komunitas Kristiani dapat menginspirasi masyarakat Indonesia untuk terus membangun hidup dalam semangat Bhineka Tunggal Ika.

\section{METODE PENELITIAN}

Studi penelitian ini menggunakan metode studi kepustakaan dalam tinjuan pendekatan fenomenologi. Pendekatan fenomenologi adalah metode penelitian yang menyumbang interpretasi kebenaran yang tidak didasarkan pada proses penalaran

\footnotetext{
${ }^{8}$ Armada Riyanto, Menjadi Mencintai: Berfilsafat Sehari-Hari (Yogyakarta: Kanisius, 2013).

${ }^{9}$ Henri J. M Nouwen, Keheningan Sebagai Pusat Hidup Komunitas Yang Menyuburkan Dalam Komunitas Alternatif, ed. Ignatius Suharyo (Yogyakara: Kanisius, 1998).
} 
deduktif tetapi dalam pengalaman konkret subyek dalam melakukan peziarahan hidup. Jika dalam penelitian kuantitatif temuan berada dalam pertaruhan signifikansi komponen-komponen penelitian, dalam penelitian fenomenologi melampaui statement signifikan. Temuan riset fenomenologi ada pada frameworks bahasa yang melukiskan agility real pengalaman subyek. ${ }^{10}$ Dunia pengalaman manusia adalah dunia sejarah manusia (Historisitas) yang mendulang nilai-nilai-nilai kehidupan manusia. Fenomenologi adalah seni mempertanyakan kemapanan dan kedangkalan. Penelitiannya mengedepankan pengalaman manusia bukan formalisme kebenarankebenaran. Berdasarkan hal tersebut dalam studi penelitian ini panggilan orang Kristiani sebagai duta kasih Allah yang di dasarkan pada pengalaman intoleransi, radikalisme agama dan bom bunuh diri di depan Gereja Katedral Makasar 28 Maret 2021 yang lalu. Peristiwa ini mendulang kebenaran betapa kehidupan bersama saat ini dirongrong oleh prilaku yang memecah belah kehidupan bersama. Peristiwa ini membangkitkan kesadaran orang Kristiani untuk mewujudkan panggilannya sebagai duta kasih Allah. Sebab dalam pengalaman sehari-hari kasih dapat merobohkan kebencian dan permusuhan. Dengan kata lain, dalam penelitian fenomenologi produk penelitiannya melampaui batas-batas pengalaman personal (meski berasal dari fundasi pengalaman subyek), keilmiahannya mengatasi kadar rasio signifikan sebab bahasa pengalaman berada kedalaman pengalaman subyek. ${ }^{11}$

Sumber data penelitian ini dibagi menjadi dua bagian utama yakni sumber data primer dan sumber data sekunder. ${ }^{12}$ Sumber data primer diperoleh dari Kitab Suci, Ajaran Gereja secara khusus surat dan ensiklik yang dikeluarkan oleh Paus Yohanes Paulus II dan Paus Fransiskus tentang Belas Kasih dan Kerahiman Allah. Sumber data sekunder di himpun dari jurnal-jurnal ilmiah, surat kabar online dan buku-buku yang berbicara tentang tugas dan panggilan orang Kristiani di tengah dunia dan sejarah terbentuknya bangsa Indonesia. Sumber-sumber ini dihimpun dan dianalisis secara mendalam dalam sudut padang fenomenologi. Selanjutnya dijadikan tesis penelitian berupa gagasan peran komunitas kristiani untuk membangkitkan semangat kebinekaan Bangsa Indonesia.

\section{HASIL DAN PEMBAHASAN}

\section{Gereja di tengah Kebinekaan Bangsa Indonesia}

Indonesia adalah bangsa yang plural terdiri dari beribu-ribu pulau, bermacammacam etnis, agama suku dan bahasa namun satu dalam Negara Kesatuan Republik Indonesia di bawah falsafah Pancasila dengan semboyan Bhineka Tunggal Ika. Semangat kesatuan dan persatuan ini tumbuh dan berkembang dalam satu proses sejarah bersama, dalam kesatuan ekonomi dan pemerintahan zaman Sriwijaya,

${ }^{10}$ Edmund Husserl, Ideas Pertaining to a Pure Phenomenology and to a Phenomenologycal Philosophy, ed. F. Kersten, First Book. (The Hague: Nijhoff, 1982).

${ }^{11}$ Armada Riyanto, Kearifan Lokal-Pancasila Butir-Butir Filsafat "Keindonesiaan," ed. Armada Riyanto et al., Kearifan Lokal-Pancasila Butir-Butir Filsafat Keindonesian (Yogyakarta: Kanisius, 2015).

12 Poppy Yaniawati, “Penelitian Studi Kepustakaan," Penelitian Kepustakaan (Liberary Research), no. April (2020): 15. 
Majapahit, Sumpah Pemuda 28 Oktober 1928 dan dalam kesatuan tekad membentuk Negara Republik Indonesia tahun 1945. Kebersamaan ini dilandasi pengalaman senasib dan sepenanggungan karena sama-sama dijajah. Penderitaan bersama ini menumbuhkan semangat solidaritas dan tenggang rasa di antara anak-anak bangsa yang tersimpul dengan indah dalam rumusan Pancasila. Dalam semangat kebersamaan itu suku-suku bangsa yang bineka tersebut bertumbuh menjadi satu kebudayaan nasional dalam satu wilayah kesatuan yang secara geografis tidak bisa dipisahkan. ${ }^{13}$

Namun pada kuarter keempat menuju 100 tahun kemerdekaan Indonesia terjadi sejumlah persoalan yang bertentangan dengan semangat persatuan dan kesatuan yang tampak dalam intoleransi, radikalisme agama dan etnosentrisme. Di berbagai daerah muncul sikap primordialisme yang dibalut semangat otonomi daerah yang agak menyim-pang dari semangat kebangsaan. ${ }^{14} \mathrm{Hal}$ ini nampak dalam merebaknya keinginan daerah-daerah mulai dari tingkat desa hingga provinsi bahkan wilayah tertentu yang ingin merdeka menjadi negara sendiri. Kondisi ini diperparah dengan semakin meningkatnya radikalisme agama dan ekstremismeterorisme. Sebagaimana dikatakan Ridwan Habib, pakar Terorisme asal Universitas Indonesia kepada media Republika, Senin 29 Maret 2021 bahwa, salah satu motif pelaku terorisme ialah keinginan para pelaku untuk menunaikan ajaran yang diterimanya guna dipraktikkan secara global. ${ }^{15}$ Melalui tindakan tersebut para pelaku dan para teroris lain di dunia ingin membentuk rasa saling tidak percaya antara pemerintah dengan masyarakat, dan antara masyarakat yang satu dengan kelompok masyarakat lain. Melalui cara ini mereka dapat menguasai negara tersebut seperti yang terjadi di Suriah. Singkat kata, agama dijadikan amunisi untuk membenarkan dan memperlancar tindakan serangan teror kepada masyarakat dan elemen lain dalam negara guna menguasai wilayah tersebut. ${ }^{16}$

Berhadapan dengan tindakan tersebut, Gereja sebagai salah satu lembaga religius dalam masyarakat ditantang untuk menentang tindakan ekstremismeterorisme dengan membudayakan semangat kasih. Gereja dapat memulainya dengan menjalin dialog. Semangat dialog ini sebenarnya sesuai dengan situasi sosial masyarakat Indonesia yang sangat menjunjung tinggi budaya gotong royong, suatu falsafah dan kebijaksanaan orang Indonesia dalam mendekati sesame. ${ }^{17}$ Melalui pendekatan ini, Gereja memberi kesaksian kepada dunia bahwa agama tidak menebarkan kebencian dan perang, termasuk juga Islam yang kerapkali dituduh

${ }^{13}$ Hanafi Hanafi, "Hakekat Nilai Persatuan Dalam Konteks Indonesia (Sebuah Tinjauan Kontekstual Positif Sila Ketiga Pancasila)," Jurnal Ilmiah Pendidikan Pancasila dan Kewarganegaraan 3, no. 1 (2018): 56-63.

${ }^{14}$ Agung Hartoyo, "Menggugah Kesadaran Nasional Mempengaruhi Kebhinekaan Indonesia," Jurnal Pendidikan Sosiologi Dan Humaniora 01 (2010): 132-147.

15 Suryarandika, "Menebak Motif Di Balik Bom Bunuh Diri Makassar."

16 Frederikus Fios, "Kiprah Agama Dalam Melawan Terorisme," Humaniora 2, no. 2 (2011): 1329-1338.

17 Deasy Elisabeth Wattimena and Kalalo, "Membangun Makna Teologis Gotong Royong Dalam Memperkuat Kebhinekaan," Epigraphe:Jurnal Teologi dan Pelayanan Kristiani 6, no. 1 (2020): 1-15. 
sebagai agama yang mengajarkan radikalisme dan terorisme. ${ }^{18}$ Stigma negatif terhadap Islam muncul karena perilaku dan sikap beberapa orang dan kelompok muslim garis keras yang mengaku sebagai Islam sejati tetapi anti kebhinekaan dan anti Pancasila. ${ }^{19}$ Label negatif ini didukung oleh laporan tindakan intoleransi yang dilakukan oleh beberapa kelompok umat Islam dan tokoh-tokoh Islam radikal seperti ujaran kebencian yang dilakukan Habib Rizieq Shihab atau Ustadz Yahya Waloni. ${ }^{20}$

Padahal agama pada hakikatnya adalah kasih dan sumber perdamaian. Dalam iman Katolik, kasih itu diwujudkan dalam tindakan pelayanan dan kemurahan hati kepada semua orang tanpa memandang suku, ras, etnis dan agama. Hal ini digambarkan dengan sangat indah oleh Paus Fransiskus dalam ensiklik Fratelli Tutti Art. 56 dalam kisah Seorang Asing Di Jalanan. Dalam kisah ini Paus Fransiskus mengajak orang Katolik untuk mencintai sesama tanpa batas, karena dengan cara ini Gereja menganugerahkan martabat yang tak terhingga kepada seluruh umat manusia. ${ }^{21}$ Sebab ketika Gereja percaya bahwa Kristus menumpahkan darah-Nya kepada semua orang, itu berarti tidak ada seorang pun berada di luar cakupan kasih universal-Nya. Dengan kata lain Paus hendak menegaskan kasih dan kemurahan hati adalah identitas utama Gereja di dunia dan tanpa kasih Gereja kehilangan wajah-Nya. $^{22}$

Persoalan yang sering terjadi dewasa ini kemurahan hati disadari sebagai tantangan yang dihadapi Gereja dimana Allah seringkali dikaitkan dengan balas dendam, kebencian dan kekerasan. Tidak sedikit orang yang beragama melakukan tindakan kekerasan dan kejahatan atas nama Allah. ISIS sebagai salah satu kelompok teroris menggunakan ayat-ayat suci Alquran untuk menarik perhatian pengikutnya. Di Indonesia fenomena ini tumbuh dalam bentuk narasi satu ummah yang terjelma dalam aksi berkumpulnya umat Islam di Monumen Nasional (Monas) pada 2 Desember 2016 lalu. ${ }^{23}$ Karena itu tugas pertama Gereja sebagai sakramen kasih ialah mewartakan pesan kerahiman Allah. Artinya Gereja tidak hanya mewartakan kebenaran paling mendalam tentang Allah, tetapi juga mewartakan kebenaran paling mendalam tentang manusia. ${ }^{24}$ Kebenaran yang paling mendalam

18 Muh Khamdan, "Rethinking Deradikalisasi: Konstruksi Bina Damai Penanganan Terorisme," Addin 9, no. 1 (2015): 181-204.

${ }^{19}$ Choirul Anwar, "Islam Dan Kebhinekaan Di Indonesia: Peran Agama Dalam Merawat Perbedaan," Zawiyah: Jurnal Pemikiran Islam 4, no. 2 (2018): 1.

${ }^{20}$ Abu Bakar Dja'far, "Prosiding Seminar Nasional, Harmonisasi Keberagaman Dan Kebangsaan Bagi Generasi Milenial, Lembaga Kajian Keagamaan," Nilai-Nilai Humanisme Dalam Menjaga Harmonisasi Keragaman Masyarakat 14 (2019): 62-67.

${ }^{21}$ Paus Fransiskus, "Ensiklik Fratelli Tutti," in Seri Dokumen Gereja, ed. KWI (Jakarta: Depertemen DokumentasiI Dan Penerangan Konferensi Waligereja Indonesia, 2020).

22 Paus Fransiskus, "Misericordiae Vultus Wajah Kerahiman Allah," in Bulla Pemberitahuan

Yubileum Luar Biasa Kerahiman Paus Fransiskus 11 April 2015, 99th ed. (Jakarta: Depertemen

Dokumentasi Dan Penerangan Konferensi Waligereja Indonesia, 2015).

${ }^{23}$ Irfan Prayogi and Fernanda Putra Adela, "Populisme Islam Dan Imajinasi Politik Dalam Pilkada DKI Jakarta 2017," Politeia: Jurnal Ilmu Politik 11, no. 2 (2019): 31-43.

${ }^{24}$ Walter Kasper, Belas Kasih Allah: Dasar Kitab Suci Dan Kunci Hidup Kristiani, ed. Karmelindo (Malang, 2016). 
tentang Allah bahwa Dia adalah kasih, yang mencintai setiap orang secara utuh. Kebenaran yang paling mendalam tentang manusia bahwa Allah dalam kasih-Nya telah menciptakan manusia dengan suatu cara yang mengagumkan dan menghendaki manusia untuk hidup berdampingan satu sama lain. Kebenaran kasih itu diwujudkan Gereja pertama-tama dalam sakramen Rekonsiliasi. Sakremen Rekonsiliasi adalah suatu tempat perlindungan yang benar bagi orang berdosa dimana setiap manusia diterima dengan kasih sejati, bukan karena karena perbuatan baik yang telah ia lakukan tetapi semata-mata karena berlimpahnya kasih karunia Allah. ${ }^{25} \mathrm{Di}$ sinilah beban yang dipikul manusia kemana-kemana disingkirkan.

Dengan memberikan sakramen rekonsiliasi, Gereja menolong sesamanya termasuk umat lain untuk mengadakan suatu kesempatan baru untuk sekali lagi hidup lebih baik. Dengan cara ini Gereja mendorong siapa saja untuk bertobat dan merubah perilakunya yang jahat. Inilah kekuatan kasih Allah yang menerima siapa saja yang ingin bertobat kendati orang tersebut adalah seorang penjahat. Sebab kemurahan hati Allah jauh lebih besar dari dosa manusia. Hal yang sama yang dikatakan oleh Paus Fransiskus dalam Fratelli Tutti Art. 86 yang secara tegas mengutuk berbagai bentuk kekerasan dan berbagai bentuk nasionalisme sempit, xenofobia serta perendahan, bahkan perlakuan buruk kepada mereka yang berbeda keyakinan. ${ }^{26}$ Sebab hal ini bertentangan dengan semangat dasar semangat manusia secara khusus orang beriman yang dipanggil untuk mencintai dan melayani sesama.

Karena itu, Gereja dalam semangat kasih mengajak siapa saja yang berkehendak baik untuk menata dan memperbaharui dunia kehidupan ini. Bukan sekedar beragama dengan tekanan pada norma dan ritual tetapi bagaimana membangun hidup secara seimbang dan integral, sehingga iman terwujud dalam tindakan kasih kepada sesama. ${ }^{27}$ Dalam nada yang sama diungkapkan oleh Paus Fransiskus dalam anjuran apostoliknya Evangelii Gaudium, "Aku memimpikan suatu Gereja yang tampil sebagai seorang ibu dan gembala yang mendampingi umat seperti seorang Samaria yang baik hati, yang mau mambasuh, membersihkan dan menghidupkan kembali sesamanya". ${ }^{28}$ Melalui sikap ini, Gereja sanggup menyembuhkan luka, menghangatkan hati, setelah luluh dan terjebak dalam pertempuran di ruang kehidupan. Paus menyatakan sesungguhnya, setiap hari tersedia bagi kita suatu kesempatan baru, kemungkinan baru untuk saling bertanggungjawab dalam menciptakan proses dan perubahan-perubahan baru. Saat ini dengan pandemi Covid-19 menjadi kesempatan besar bagi kita menyatakan rasa persaudaraan yang terdalam dengan menjadi orang Samaria yang murah hati, yang menanggung rasa

25 Paus Yohanes Paulus II, “Dives In Misericordia Kaya Dalam Kerahiman,” in Ensiklik, ed. F.X. Adisusanto SJ and Bernadeta Harini Tri Prasasti, 99th ed. (Jakarta: Depertemen Dokumentasi Dan Penerangan Konferensi Waligereja Indonesia, 1980).

${ }^{26}$ Fransiskus, "Ensiklik Fratelli Tutti."

27 T. Krispurwarna Cahyadi, Kemurahan Hati: Wajah Allah- Kesaksian Gereja (Yogyakarta: Kanisius, 2016).

${ }^{28}$ F. X. Hadisumarta, "Kerahiman Allah Menurut Maria," in Kerahiman Allah, ed. Edison R. L Tinambunan (Malang: Karmelindo, 2017). 
sakit persoalan sesama. Layaknya seperti seorang musafir yang kebetulan lewat, kita dapat memulai dari bawah dan berbuat secara sangat konkret pada tingkat lokal, dan kemudian meluas hingga ke negara- negara melalui kepedulian dan perhatian terhadap sesama. ${ }^{29}$

Dengan demikian semua orang diajak terlebih khusus orang Kristiani untuk keluar menjumpai sesama dan memeluk dunia sebagaimana adanya, tanpa takut akan luka atau perasaan tidak mampu, sebab di sana kita akan menjumpai segala kebaikan yang Allah tanamkan dalam hati manusia. Akan tetapi, orang Kristiani dianjurkan tidak melakukannya sendiri sebagai individu tetapi bersama-sama dengan yang lain. Seperti orang Samaria yang menemukan pemilik penginapan untuk dapat merawat orang yang dirampok; orang Kristiani pun dipanggil untuk bersatu sebagai satu keluarga dalam komunitas daripada sejumlah kecil anggota individual saja. Hal ini ditegaskan Paus dalam Art. 78 bahwa, "Keseluruhan lebih besar daripada bagian, dan lebih besar pula daripada jumlah bagian-bagian". 30

\section{Panggilan Orang Kristiani Sebagai Duta Kasih Allah di tengah Kebinekaan}

Di tengah dunia yang diwarnai oleh persaingan, di mana umat manusia dicabikcabik oleh konflik, perang, kebencian dan penindasan, belas kasih bukanlah warna yang wajar dalam kehidupan. Apa yang sesungguhnya menjadi perhatian manusia adalah berhasil dalam kehidupan, maju dan menjadi yang pertama. Belas kasih tidak lebih daripada penghapus kecil di ujung sebuah pensil, dan digunakan kalau membuat kesalahan. Demikian belas kasih hanya dimanfaatkan kalau ada kejadian di luar perhitungan. Bagian pokok dari kehidupan adalah persaingan. Lalu pertanyaanya bagaimana persis tempat dari belas kasih dalam kehidupan manusia? Nampaknya tidak dapat dibayangkan bahwa belas kasih tidak termasuk sifat manusia. Siapapun tentu merasa sakit hati kalau dituduh tidak berbelas-kasih karena itu berarti dia kurang manusiawi. Sebab tidak dapat dibayangkan seorang manusia yang tidak mempunyai belas kasih, seperti halnya tidak dapat dibayangkan seorang manusia yang tidak manusiawi.

Aristoteles adalah salah satu filsuf yang berbicara tentang kebaikan sebagai tujuan kegiatan manusia. Menurutnya kehendak manusia dalam dirinya selalu mengejar kebaikan, sedangkan keburukan tidak pernah menjadi tujuan manusia. ${ }^{31}$ Namun, jika hidup secara manusiawi sama dengan hidup yang selalu ingin meraih kebaikan, lalu mengapa umat manusia dicabik-cabik oleh konflik, perang, kebencian dan penindasan? Mengapa perbedaaan suku, ras, agama, dan perbedaan pandangan politik menghalangi manusia untuk saling mendekati? Mengapa manusia saling melukai, menyiksa dan membunuh?

Pertanyaan-pertanyaan mendasar seperti inilah yang mestinya direnungkan oleh bangsa Indonesia secara khusus orang Kristiani di quarter ke- 4 menuju 100 tahun kemerdekaan Indonesia. Mengapa bangsa Indonesia begitu mudah dipola-

\footnotetext{
${ }^{29}$ Fransiskus, "Ensiklik Fratelli Tutti."

30 Ibid.

31 Riyanto, Menjadi Mencintai: Berfilsafat Sehari-Hari.
} 
risasi menurut suku, ras dan agama. Bagaimana mungkin manusia Indonesia begitu mudahnya membenci dan menghabisi sesama hanya karena perbedaan kepercayaan. Hal yang sama juga direnungkan oleh Paus Fransiskus dan mengajak orang Kristiani untuk merenungkan dengan baik persoalan mendasar ini. Bagaimana mungkin manusia bertumbuh semakin jauh satu sama lain, dan langkah ke depan untuk membangun dunia yang semakin bersatu dan adil mengalami kemunduran baru dan dramatis. ${ }^{32}$ Karena itu, Paus Fransiskus dalam Art. 60 Fratelli Tutti mengajak semua orang secara khusus orang Kristiani untuk mengarahkan perspektif pada perintah Yesus "Hendaklah kamu murah hati, sama seperti Bapamu adalah murah hati" (Luk 6:36). ${ }^{33}$

Hal yang sama juga direnungkan Henri Nouwen (1932-1996) seorang guru spiritualitas Kristiani modern agar menyadari dengan sungguh perintah Yesus tersebut. Menurut Nouwen, belas kasih Allah adalah belas kasih yang tidak diwarnai oleh persaingan. ${ }^{34}$ Allah menunjukkan kasih-Nya dengan mengambil bagian dalam hidup manusia, berbagi rasa dengan penderitaan dan kesulitan manusia, serta menanggung semua suka-duka hidup manusia. Dengan penegasan ini, kita dapat mengerti arti belas kasih yang sesungguhnya, bahwa belas kasih bukanlah suatu pandangan ke bawah dari orang-orang yang mempunyai hak-hak istimewa kepada mereka yang papa. Bukan suatu uluran tangan dari atas kepada mereka yang kurang beruntung, sebaliknya pergi secara langsung dimana penderitaan paling berat dirasakan. Hal ini membuat kita mengerti rahasia pelayanan kasih yang ditunjukkan oleh Sta. Theresia dari Calcuta dan St. Vincentius yang pelayananya membawa kehidupan bagi orang kecil, sakit, menderita dan yang terbuang.

Berdasarkan hal itu, di hadapan jutaan orang yang menderita kelaparan, kedinginan, perang, rasisme dan terorisme, orang Kristiani tidak bisa tinggal diam. Mereka dipanggil dan diutus untuk menjadi duta kasih Allah. Karena Allah sendiri telah berpihak kepada mereka yang menderita dalam diri Yesus. Suatu keberpihakan yang menuntut kita pergi ke tempat dimana ada luka dan penderitaan, ikut serta dalam keterpecahan, ketakutan, kebingungan dan kecemasan orang lain. Sebagaimana yang telah dilakukan oleh Nelson Mandela yang memperjuangkan keadilan dan kebebasan di Afrika Selatan. Mandela menghabiskan 20 tahun di penjara karena penentangannya terhadap hukum apartheid, yaitu sistem pemisahan rasyang diterapkan oleh pemerintah kulitputih di Afrika awal abad ke20 hingga tahun 1990, atau perjuangan Martin Luther King yang membantu meningkatkan kesadaran akan ketidaksetaraan ras kulit hitam di Amerika. Perjuangannya akhirnya menyebabkan perubahan politik yang signifikan di Amerika. ${ }^{35}$ Keberanian menghadapi situasi dalam kerendahan hati penuh bela rasa itulah yang memung-

32 Fransiskus, "Ensiklik Fratelli Tutti.”

33 Ibid.

${ }^{34}$ Nouwen, Mcneill, and Morrison, Sehati Seperasaan.

35 Okta Hadi Nurcahyono, "Pendidikan Multikultural Di Indonesia: Analisis Sinkronis Dan Diakronis," Habitus: Jurnal Pendidikan, Sosiologi, \& Antropologi 2, no. 1 (2018): 105. 
kinkan orang Kristiani dapat memberi kesaksian kepada dunia bahwa, kebinekaan bukanlah penghalang untuk saling mendekati satu sama lain. Kalau setiap orang Kristiani memandang belas kasih dengan cara ini, menjadi jelas bahwa kemajemukan menjadi kekayaan dan sarana bagi setiap orang untuk saling berlombalomba mewujudkan kasihnya.

Ide semacam ini bagi sebagian orang terkesan naif, romantis atau paling sedikit tidak realistis. Kendati demikian, sulit untuk tidak melihat bahwa tidak jarang keputusan-keputusan yang bermula dari pemikiran tentang keadilan yang seharusnya membantu pemenuhan individu-individu atau kelompok-kelompok masyarakat dalam kenyataanya tidak berjalan sesuai yang diharapkan. Penegak hukum sebagai pemegang keadilan kerapkali tidak berjalan adil, sehingga rakyat merasakan jurang ketidakadilan antara penguasa dan orang kebanyakan. Koruptor yang merampok uang rakyat bebas berkeliaran, sedangkan mereka yang lemah secara ekonomi dan status sosial begitu mudahnya diseret ke meja hijau. Kondisi ketidakadilan semacam inilah yang sesungguhnya menjadi latar belakang tindakan terorisme karena para pelaku merasa tidak adil dan berdaya dalam menyampaikan aspirasinya melalui cara yang lazim dan terlegitimasi secara formal. ${ }^{36}$ Dengan kata lain dalam kehidupan sehari-hari keadilan tidaklah cukup, sebab keadilan pada kenyataanya kerap kali mengarah ke penolakan dan penghancuran diri sendiri, bila kekuatan yang lebih besar yaitu kasih tidak dibiarkan masuk membentuk kehidupan manusia dalam berbagai dimensinya. Di sinilah orang Kristiani sebagai murid Kristus dipanggil untuk menjadi duta kasih Allah dengan ikut ambil bagian secara kritis dalam isu-isu sosial yang ada di Masyarakat.

\section{Komunitas Kristiani Sebagai Sarana Menghayati Hidup Berbelas Kasih di tengah Kebinekaan Bangsa Indonesia}

Persoalan pokok yang menjadi pusat perhatian pada bagian ini adalah bagaimana orang Kristiani menjadi murid Kristus yang berbelas-kasih di tengah kebinekaan bangsa Indonesia. Mengapa ratusan tahun Gereja Katolik hadir di Indonesia masalah SARA tetap terus terjadi. Tidak jarang masalah tersebut terkait langsung dengan Gereja Katolik seperti pencemaran hosti di Maumere 1995 dan masalah Tibo. ${ }^{37}$ Meski masalah-masalah tersebut tidak bermula dari orang Kristiani tetapi reaksi spontan umat Kristiani yang mengancurkan mesjid dan membakar usaha milik umat muslim perlu menjadi bahan permenungan. Bagaimana kasih tidak hanya menjadi jargon kosong tetapi sungguh dihidupi dan dihayati dalam kehidupan umat Kristiani. Tepatnya bagaimana amanat agung Kristus untuk mencintai sesama seperti mencintai diri sendiri bahkan sampai mengorbankan nyawa dihidupi sebagai identitas Kristiani. Bagaimana kasih Kristus diwujudnyatakan dalam kehidupan sehari-hari umat khususnya di tengah kebinekaan bangsa Indonesia sehingga kehadiran umat Kristiani sungguh menjadi duta kasih Allah.

\footnotetext{
${ }^{36}$ Atom Ginting Munthe, "Teorisme: Gejala Kriminal Media Mutakhir," Jurnal Hukum Pro Justisia 25, no. 1 (2007): 1-8.

37 David Krisna Alka, "Abdul Rasyid Wahab Pesan Kebinekaan Dari Tanah Sikka, Maumere," Maarif 13, no. 2 (2018): 87-93.
} 
Kehidupan Kristiani awal menunjukkan bahwa hidup yang berbelas-kasih adalah hidup bersama. Gereja Perdana menunjukkan secara mengagumkan bagaimana budaya kasih diwujudkan dalam komunitas. Kisah Para Rasul menceritakan bagaimana Perjamuan Tuhan dihubungkan dengan perjamuan agape (kasih), dan melayani meja sudah ada sejak dalam komunitas awal di Yerusalem (Kis 6:1-4). Pada zaman Bapa Gereja sekitar abad 2 dan abad ke-3, Tertullianus melaporkan bahwa cara kaum Kristiani memperhatikan kaum fakir miskin, sangat mengagumkan bagi kaum kafir. Kaum kafir berkata, "Lihatlah bagaimana mereka itu saling mengasihi". ${ }^{38}$ Dengan kata lain, sejarah hidup jemaat perdana membuktikan bahwa cara hidup bersama dalam komunitas mengubah hati seseorang. Sebutlah Saulus menjadi Paulus, Agustinus yang bertobat dan beberapa tokoh besar lainnya dalam Gereja yang diubah oleh Allah lewat kesaksian kasih hidup komunitas.

Semua hal di atas menjadi contoh bagaimana kasih dapat menjadi penawar di tengah gejala nasionalisme yang lamur, ekstrim, penuh kebencian dan agresif yang akhir-akhir ini semakin meningkat. ${ }^{39}$ Komunitas Kristiani karenanya menjadi oase di tengah kekacauan dunia. Santo Paulus menjelaskan dengan sangat konkrit apa yang dimaksudkan dengan hidup dalam komunitas kasih dimana di dalamnya ada nasihat, ada penghiburan, ada persekutuan Roh, ada kasih mesra dan belas kasihan, karena itu menurutnya orang Kristiani hendaknya sehati sepikir dalam satu kasih, satu jiwa dan satu tujuan (Flp 2:1-2). Berkaitan dengan hal ini Paulus menekankan hidup komunitas dengan mengatakan, "Janganlah mencari kepentingan sendiri tetapi hendaklah dengan rendah hati seorang menganggap yang lain lebih utama dari dirinya sendiri" (bdk. Flp 2:2-4).

Hidup berkomunitas dengan demikian adalah hidup dimana persahabatan dengan Kristus mewujud dalam persaudaraan baru yang terjadi diantara pengikutNya. Tetapi mesti disadari bahwa hidup bersama dalam komunitas tidak didasarkan karena kesamaan hobi, kesesuaian intelektual, daya tarik jasmani, kesamaan dalam cita-cita atau karena latar belakang budaya dan agama yang sama. Semua ini memang dapat menjadi unsur-unsur yang penting dalam hubungan yang baik, tetapi tidak memberi jaminan bagi hidup komunitas. Kualitas utama dari sebuah komunitas adalah keyakinan yang mendalam bahwa orang dipersatukan oleh Allah. Untuk memahami hal ini baiklah mengambil sebuah contoh dari kehidupan Thomas Merton, seorang pertapa Trapis. Sebagai seorang kritikus yang berpengaruh pada tahun seribu sembilan ratus enam puluhan, Merton sedikit sekali membaca surat kabar, dan tidak pernah melihat televisi atau mendengarkan radio. Meski demikian, tanggapannya terhadap kebutuhan-kebutuhan dunia penuh keterlibatan. Merton dapat mendengar peristiwa-peristiwa yang terjadi pada zamannya dan dalam keheningan dan merenungkan bagaimana ia dapat menjadi abdi bagi saudara-

\footnotetext{
${ }^{38}$ Kasper, Belas Kasih Allah: Dasar Kitab Suci Dan Kunci Hidup Kristiani.

${ }^{39}$ Fransiskus, "Ensiklik Fratelli Tutti."
} 
saudaranya ${ }^{40}$ Contoh lain adalah Santo Fransiskus Xaverius yang berjalan sendiri mengarungi berbagai benua untuk mewartakan Injil. Kekuatannya berasal dari keyakinan yang mendalam bahwa dia merupakan anggota dari satu komunitas (Gereja) yang mendukungnya dengan doa dan persaudaraan.

Kedua contoh ini menunjukkan pentingnya komunitas dalam hidup Kristiani. Penting bagi orang Kristiani untuk menggingat bahwa, hidup komunitas bukan sebagai hidup bersama dalam satu rumah, makan dan berdoa bersama atau mengerjakan proyek bersama. Memang semua ini dapat membentuk komunitas, akan tetapi komunitas sendiri adalah realitas yang jauh lebih dalam. Jean Vanier menjelaskan hal ini dengan mengatakan komunitas adalah tempat kegelapan, rasa marah, iri hati, dan sikap bermusuhan yang tersembunyi dalam hati nyata kelihatan. Dalam komunitas sesungguhnya setiap orang mengalami rasa sakit, karena dalam komunitas orang tidak lepas dari konflik maka setiap orang perlu mengalami "kematian" dan kehilangan. ${ }^{41}$ Tetapi komunitas juga adalah tempat mengalami kebangkitan. Konflik dalam komunitas terjadi karena adanya ketegangan antara nilai-nilai dunia dan nilai-nilai komunitas, antara kebersamaan dan ketidaktergantungan. Jadi hidup dalam komunitas tidak sekedar tinggal bersama dan membuat keputusan bersama.

Sebagai pendiri komunitas L'Arche yaitu komunitas yang terdiri dari orangorang yang cacat mental, Jean Vanier mengenal dengan baik apa artinya hidup dalam sebuah komunitas. Komunitas yang terpanggil bagi Jean Vanier adalah komunitas yang membuat orang bersikap terbuka dan mau menerima risiko. Seperti halnya ada mitos mengenai perkawinan, demikian juga bagi Jean Vanier ada mitos mengenai komunitas. Mitos perkawinan adalah suami isteri hidup bahagia selamalamanya. Kenyataannya perkawinan adalah kehidupan seorang pria dan wanita yang dipanggil untuk mengorbankan egoisme pribadi mereka di atas altar agar mereka menjadi satu. ${ }^{42}$ Oleh karena itu melalui hidup bersama dalam komunitas, orang Kristiani dapat melayani satu sama lain dengan kasih sehingga orang akan melihat dan berkata, "Lihat bagaimana mereka saling mengasihi, bagaimana mereka dapat melayani sesama dan bagaimana mereka berdoa kepada Tuhan mereka" ${ }^{43}$ Semangat inilah yang oleh Agustinus menjadi tujuan hidup Kristiani yakni menjadi tanda yang nyata akan hidup sehati sejiwa. Dengan cara ini orang Kristiani membuktikan bahwa hidup yang benar adalah hidup dalam persekutuan. Cara hidup komunitas ini karenanya menjadi sekolah bagi orang Kristiani untuk menerima perbedaan dalam hidup bermasyarakat. Kemajemukan menuntut setiap

\footnotetext{
${ }^{40}$ Nouwen, Keheningan Sebagai Pusat Hidup Komunitas Yang Menyuburkan Dalam Komunitas Alternatif.

41 Jean Vanier, "Komunitas: Tempat Orang Saling Mengikatkan Diri, Memberi Perhatian, Dan Mendukung Dalam Perutusan," in Komunitas Alternatif: Hidup Bersama Menerbarkan Kasih, ed. I. Suharyo (Yogyakarta: Kanisius, 1998).

42 Ibid. Alternatif.

${ }^{43}$ Nouwen, Keheningan Sebagai Pusat Hidup Komunitas Yang Menyuburkan Dalam Komunitas
} 
orang dan setiap kelompok untuk mengorbankan kepentingannya yang bertentangan dengan cita-cita bersama bangsa Indonesia yang satu dan berdaulat.

Oleh sebab itu semangat belas kasih yang menjiwai komunitas Kristen diharapkan dapat menjadi jembatan kasih di tengah kebinekaan bangsa Indonesia. Sebab di dalam komunitas Kristiani, Kristus hadir sebagai Sang Pengantara yang membuat semua anggotanya menyadari bahwa semua manusia entah dari ras, golongan bahkan agama apapun dipanggil pada tujuan yang sama dan satu yaitu menjadi anak-anak Allah. ${ }^{44}$ Oleh karena itu di dalam komunitas Kristiani mata dan telinga akan selalu terbuka untuk segala sesuatu yang terjadi sehingga orang dapat mengerti tentang kelaparan, penindasan dan penyiksaan. Dengan demikian komunitas Kristiani adalah tempat orang memberi perhatian satu sama lain dimana setiap orang dipanggil untuk mencintai sesama sebagaimana adanya, dengan luka-luka, kekurangan dan kelebihannya bukan sebagaimana yang dikehendaki.

Menurut Henri Nouwen salah satu yang paling tragis pada zaman kita adalah kita lebih tahu tentang kemalangan dan penderitaan dunia tetapi semakin tidak mampu menanggapinya. ${ }^{45}$ Pameran penderitaan yang berlebihan seringkali membuat orang bisu secara psikis. Budi manusia tidak tahan untuk selalu diingatkan akan hal-hal yang mengganggu apa yang sedang dikerjakan. Kalau membiarkan seluruh berita tentang penderitaan masuk ke dalam hati dan sanubari, manusia akan begitu dibebani oleh absurditas kehidupan dan menjadi lumpuh. Naluri efisiensi manusia menuntut adanya sistem penyaringan mental. Dengan sistem itu manusia dapat melunakkan pengaruh berita sehari-hari. Lebih dari itu pemberitaan tentang penderitaan manusia pada tingkat yang begitu masal tidak hanya menimbulkan orang bisu secara psikis, tetapi juga dapat menimbulkan sikap bermusuhan. Karena itu persoalanya adalah bagaimana orang Kristiani dapat melihat penderitaan dunia ini dan hatinya tergerak seperti halnya hati Yesus tergerak ketika melihat orang banyak yang tidak mempunyai apa pun untuk dimakan (Mat 14:14). Pertanyaan ini begitu mendasar di mana kita begitu banyak melihat penderitaan akan tetapi sedikit sekali hati kita tergerak. Di sinilah peran komunitas Kristiani untuk masuk dalam hubungan yang semakin mendalam dengan Kristus dan masuk dalam hubungan mistik dengan Allah, yakni ikut ambil bagian dalam penderitaan dunia.

Berkaitan dengan lunturnya semangat kebinekaan dalam kehidupan berbangsa dan bernegara di Indonesia, komunitas Kristiani dapat menjadi wadah persaudaraan bagi orang Kristiani untuk melihat kemajemukan bukan sebagai penghalang untuk saling mendekati satu sama lain. Tetapi peluang bagi siapa saja untuk menyatakan kasih. Hal ini dijelaskan dengan sangat baik oleh Agustinus bahwa tanpa komunitas persaudaraan yang disatukan dalam kasih, ikatan kesatuan tersobek dan perbuatan-perbuatan baik menjadi seperti ranting-ranting yang dipotong dari pohon anggur. ${ }^{46}$ Penegasan ini secara mendasar memberi kesaksian

${ }^{44}$ Fransiskus, "Ensiklik Fratelli Tutti."

${ }^{45}$ Henri. J. M. Nouwen, The Selfless Way of Christ, ed. Rafael Isharianto (Malang: Dioma, 2008).

${ }^{46}$ Kasper, Belas Kasih Allah: Dasar Kitab Suci Dan Kunci Hidup Kristiani. 
bahwa kehadiran Allah yang berbelas-kasih di dalam dunia justru dengan cara kita hidup bersama dan berkerja sama dengan orang lain.

Kita cenderung berpikir bahwa belas kasih adalah sebuah keunggulan pribadi, sehingga dengan mudah melupakan ciri pokoknya yang komunal. Oleh karena itu, Agustinus mengingatkan bahwa keberadaan sesama manusia atau teman, berperan sangat penting dalam perjalanan manusia menuju Allah. ${ }^{47}$ Sebab kita tidak dapat mencapai Allah hanya dengan akal budinya saja. Solidaritas, partisipasi dan kebersamaan merupakan konsep kunci dalam perjalanan hidup menuju ke hadirat Allah. Oleh karena itu, kebersamaan dalam kemajemukan membuat kita sadar bahwa tugas kita sesungguhnya menjadikan satu sama lain sebagai kawan perjalanan dalam lorong yang sama. Berkaitan dengan hal tersebut komunitas Kristiani dapat memulainya dengan menunjukkan keramahan dan kemurahan hati. Panggilan ini menjadi saat yang berahmat dan istimewa mengingat situasi Bangsa Indonesia yang menjadikan perbedaan sumber kebencian dan permusuhan.

Kebersamaan dalam komunitas karenanya menjadi cara bertindak umat Kristiani untuk menjumpai sesama, menyatakan perhatian dan kepedulian kepada siapapun tanpa memandang ras, suku dan agama. Kebersatuan dalam komunitas sebenarnya merupakan pernyataan terdalam dari identitas murid-murid Kristus. Sedangkan kemurahan hati dan belas kasih adalah tanda identitas kebersatuan orang Kristiani dengan Allah dan sekaligus tanda kesaksian akan imannya kepada Allah di tengah dunia. ${ }^{48}$ Hal ini ditegaskan oleh Paus Fransiskus dengan mengatakan, "Saya lebih menyukai Gereja yang memar, terluka dan kotor karena keluar di jalan-jalan daripada Gereja yang sakit karena menutup diri dan nyaman melekat pada rasa nyamannya sendiri" ${ }^{49}$ Demikianlah Gereja yang dikehendaki sebagai komunitas yang bermurah hati, komunitas yang berbelas-kasih, agar dengan demikian orang Kristiani semakin menjadi sakramen, tanda dan sarana belas kasih Allah di dunia. Gagasan ini lahir dari keberadaan orang Kristiani sebagai tubuh mistik Kristus di dunia. Sebagai anggota tubuh Kristus, orang Kristiani adalah sakramen kehadiran Kristus yang efektif dan terus-menerus di dunia. Dengan demikian komunitas Kristiani adalah sakramen kerahiman. Sebab dalam dan melalui komunitas Kristiani realitas dan hakikat diri Allah sebagai kasih semakin ditegaskan dan dinyatakan terlebih dan terutama dalam tindakan kasih, lewat pelayanan kemurahan hati. Tujuannya agar kemurahan hati Allah kembali diwartakan, diwujudkan dan dirayakan di tengah kebinekaan. Dengan cara berada yang demikian orang Kristiani dapat menyumbang dan mempererat semangat kebinekaan Bangsa Indonesia.

Pada tahap ini mungkin pertanyaan yang muncul adalah bagaimana dapat membangun sebuah komunitas? Apa yang dapat dilakukan supaya komunitas itu berdiri? Pertanyaan-pertanyaan semacam ini sepertinya muncul dari hati yang

47 Ibid.

48 Fransiskus, "Ensiklik Fratelli Tutti."

49 Paus Fransiskus, “Evangelii Gaudium,” in Evangelii Gaudium, Seri Dokum., vol. 94 (Jakarta: Depertemen Dokumentasi Dan Penerangan Konferensi Waligereja Indonesia, 2013). 
cemas. Pertanyaan yang muncul kiranya dimana saya dapat melihat sebuah komunitas terbangun? Kalau kita menjadi peka terhadap adanya komunitas di sekitar, kita dapat melihat titik awal yang cocok untuk membangun komunitas. Mengenai hal ini baiklah untuk melihat ilustrasi tentang cara menaburkan benih. Adalah lebih masuk akal untuk menaburkan benih di tanah yang sudah tampak menumbuhkan benih daripada ke sana kemari bingung memikirkan bagaimana cara membuat tanah subur. Demikian halnya dalam membangun komunitas lebih baik menemukan langkah awal untuk mempersatukan dan menghimpun anggota dalam komunitas yang sudah ada, sehingga para anggotanya mengalami bahwa diri mereka diterima, kekuatan mereka diakui.

Sebagai calon imam yang akan bekerja di Gereja paroki sebenarnya ada banyak komunitas-komunitas yang dapat dikembangkan seperti SEKAMI (Serikat Anak-anak Misioner), OMK (Orang Muda Katolik), SEKAR (Serikat Kerasulan Remaja) dan lain-lain. Semua ini dapat menjadi sarana untuk mewujudkan kasih. Pengalaman pastoral selama 8 bulan di Paroki St. Antonius Padua, Mbeling Flores NTT tahun 2018/2019 membantu saya untuk mengembangkan semangat kasih persaudaraan dengan baik dalam komunitas. Salah satu organisasi yang dipercayakan kepada saya untuk dikembangkan adalah SEKAMI (Serikat Kerasulan Misioner). Anggota organisasi ini terdiri dari anak-anak. Umumnya berumur 8-12 tahun yang sedang duduk dibangku Sekolah Dasar. Hal yang mendorong saya untuk terlibat secara aktif dalam komunitas SEKAMI karena Keuskupan Ruteng menjadikan paroki St. Antonius Padua, Mbeling sebagai Paroki Ramah Anak. Mbeling adalah salah satu paroki di Keuskupan Ruteng yang rawan konflik. Beberapa wilayah di paroki Mbeling mempunyai sejarah konflik akibat urusan kepemilikan tanah. Meski konflik tanah tersebut sudah selesai pada tingkat pengadilan tetapi bibit permusuhan di antara kelompok yang terlibat masih berpotensi meledak. Hal ini menimbulkan kekhawatiran baik pada tingkat keuskupan maupun paroki. Karena itu fokus perhatian saya adalah kelompok anak-anak yang pada dasarnya tidak mengerti dan memahami persoalan dan sengketa yang melibatkan orang tua mereka. Saya yakin bahwa dengan menumbuhkan semangat kasih persaudaraan dan kebersamaan di antara anak-anak, maka sekat-sekat yang ada di masyarakat dapat dihilangkan.

Contoh lain yang dapat dijadikan teladan bagaimana komunitas dapat membantu untuk mewujudkan kasih di tengah kebinekaan seperti yang dilakukan oleh para frater Diosesan Regio Jawa, Makassar, dan Kalimantan yang belajar merawat kebhinnekaan bersama perwakilan majelis agama dalam Forum Kerukunan Umat Beragama (FKUB) DKI Jakarta pada Juli 2020 di Pusat Pastoral Keskupan Agung Jakarta (KAJ) Samadi Klender, Jakarta Timur. Dalam komunitas ini para frater menemukan tantangan kebhinnekaan di Jakarta bukan karena konflik agama, tapi dominasi politik dan ekonomi. Karena itu dalam kegiatan tersebut para frater mengangkat keprihatinan tentang lunturnya nilai persatuan bangsa yang disadari 
sudah dimulai dari dalam keluarga. ${ }^{50}$ Dari kegiatan tersebut dapat disimpulkan bahwa dalam komunitas Kristiani, ketakutan dan kemarahan dapat diubah oleh kasih Allah yang tanpa batas, sehingga hidup kita menjadi hidup yang semakin berbelas-kasih.

\section{KESIMPULAN}

Di tengah krisis hidup berbangsa dan bernegara akibat intoleransi, terorisme, dan radikalisme agama, orang Kristiani diharapkan menjadi jembatan kasih antara penderitaan dunia dan memberi tanggapan atasnya. Orang Kristiani dapat memulainya dengan hidup dalam komunitas persaudaraan dan terlibat dalam komunitaskomunitas yang ada di lingkungan sekitar. Sebab dengan terlibat dalam komunitas kasih persaudaraan ini, mata dan telinga kita akan dibantu untuk selalu terbuka sehingga dapat mengerti tentang kelaparan, penindasan dan penyiksaan. Dengan cara ini, kita dapat mencintai orang lain sebagaimana adanya, dengan luka-luka, kekurangan dan kelebihannya, bukan sebagaimana yang dikehendaki. Melalui keterlibatan ini orang Kristiani memberi harapan kepada dunia, secara khusus bangsa Indonesia yang plural bahwa, kebinekaan bukanlah penghalang dalam hidup bersama, melainkan sarana untuk memberikan kemerdekaan, kepercayaan, dan peneguhan kepada sesama. Dengan demikian orang Kristiani dapat menghormati dan mendengarkan sesama dalam semangat kasih, sehingga orang lain dapat hidup, berkembang dan menjadi anugerah. Melalui cara ini orang Kristiani menyumbang semangat persatuan dan kesatuan bangsa. Sebab disintegrasi bangsa lahir dari sikap curiga yang berujung pada tindakan ekstremisme-terorisme.

\section{REFERENSI}

Alka, David Krisna. "Abdul Rasyid Wahab Pesan Kebinekaan Dari Tanah Sikka, Maumere." Maarif 13, no. 2 (2018): 87-93.

Anwar, Choirul. "Islam Dan Kebhinekaan Di Indonesia: Peran Agama Dalam Merawat Perbedaan." Zawiyah: Jurnal Pemikiran Islam 4, no. 2 (2018): 1.

Aritonang, Arthur. "Peran Sosiologis Gereja Dalam Relasi Kehidupan Antar Umat Beragama Indonesia." TE DEUM (Jurnal Teologi dan Pengembangan Pelayanan) 9, no. 1 (2019): 69-102.

Budhi, Carolus. "Frater Projo Belajar Merawat Kebhinnekaan." Hidup Katolik. Jakarta, 2018.

Cahyadi, T. Krispurwarna. Kemurahan Hati: Wajah Allah- Kesaksian Gereja. Yogyakarta: Kanisius, 2016.

Dja'far, Abu Bakar. "Prosiding Seminar Nasional, Harmonisasi Keberagaman Dan Kebangsaan Bagi Generasi Milenial, Lembaga Kajian Keagamaan." Nilai-Nilai Humanisme Dalam Menjaga Harmonisasi Keragaman Masyarakat 14 (2019): 62-67.

Fios, Frederikus. "Kiprah Agama Dalam Melawan Terorisme.” Humaniora 2, no. 2 (2011): 1329-1338.

${ }^{50}$ Carolus Budhi, “Frater Projo Belajar Merawat Kebhinnekaan,” Hidup Katolik (Jakarta, 2018). 
Fransiskus, Paus. "Ensiklik Fratelli Tutti." In Seri Dokumen Gereja, edited by KWI. Jakarta: Depertemen Dokumentasil Dan Penerangan Konferensi Waligereja Indonesia, 2020.

- —. "Evangelii Gaudium." In Evangelii Gaudium. Vol. 94. Seri Dokum. Jakarta: Depertemen Dokumentasi Dan Penerangan Konferensi Waligereja Indonesia, 2013.

Hadisumarta, F. X. "Kerahiman Allah Menurut Maria." In Kerahiman Allah, edited by Edison R. L Tinambunan. Malang: Karmelindo, 2017.

Hanafi, Hanafi. "Hakekat Nilai Persatuan Dalam Konteks Indonesia (Sebuah Tinjauan Kontekstual Positif Sila Ketiga Pancasila).” Jurnal Ilmiah Pendidikan Pancasila dan Kewarganegaraan 3, no. 1 (2018): 56-63.

Hartoyo, Agung. "Menggugah Kesadaran Nasional Mempengaruhi Kebhinekaan Indonesia." Jurnal Pendidikan Sosiologi Dan Humaniora 01 (2010): 132-147.

Husserl, Edmund. Ideas Pertaining to a Pure Phenomenology and to a Phenomenologycal Philosophy. Edited by F. Kersten. First Book. The Hague: Nijhoff, 1982.

Kasper, Walter. Belas Kasih Allah: Dasar Kitab Suci Dan Kunci Hidup Kristiani. Edited by Karmelindo. Malang, 2016.

Khamdan, Muh. "Rethinking Deradikalisasi: Konstruksi Bina Damai Penanganan Terorisme." Addin 9, no. 1 (2015): 181-204.

Munthe, Atom Ginting. "Teorisme: Gejala Kriminal Media Mutakhir." Jurnal Hukum Pro Justisia 25, no. 1 (2007): 1-8.

Nouwen, Henri. J. M. The Selfless Way of Christ. Edited by Rafael Isharianto. Malang: Dioma, 2008.

Nouwen, Henri. J. M., Donald P. Mcneill, and Douglas A. Morrison. Sehati Seperasaan. Edited by Willem. S. G. Pau. Yogyakarta: Kanisius, 1987.

Nouwen, Henri J. M. Keheningan Sebagai Pusat Hidup Komunitas Yang Menyuburkan Dalam Komunitas Alternatif. Edited by Ignatius Suharyo. Yogyakara: Kanisius, 1998.

-_- Kembalinya Si Anak Yang Hilang; Membangun Sikap Kebapaan Dan Keputraan. Yogyakarta: Kanisius, 1995.

Nurcahyono, Okta Hadi. "Pendidikan Multikultural Di Indonesia: Analisis Sinkronis Dan Diakronis." Habitus: Jurnal Pendidikan, Sosiologi, \& Antropologi 2, no. 1 (2018): 105.

Paus Fransiskus. "Misericordiae Vultus Wajah Kerahiman Allah." In Bulla Pemberitahuan Yubileum Luar Biasa Kerahiman Paus Fransiskus 11 April 2015. 99th ed. Jakarta: Depertemen Dokumentasi Dan Penerangan Konferensi Waligereja Indonesia, 2015.

Paus Yohanes Paulus II. "Dives In Misericordia Kaya Dalam Kerahiman." In Ensiklik, edited by F.X. Adisusanto SJ and Bernadeta Harini Tri Prasasti. 99th ed. Jakarta: Depertemen Dokumentasi Dan Penerangan Konferensi Waligereja Indonesia, 1980.

Prayogi, Irfan, and Fernanda Putra Adela. "Populisme Islam Dan Imajinasi Politik Dalam Pilkada DKI Jakarta 2017.” Politeia: Jurnal Ilmu Politik 11, no. 2 (2019): 31-43. 
Riyanto, Armada. Kearifan Lokal-Pancasila Butir-Butir Filsafat "Keindonesiaan." Edited by Armada Riyanto, Johanis Ohoitimur, C.B. Mulyatno, and Otto Gusti Madung. Kearifan Lokal-Pancasila Butir-Butir Filsafat Keindonesian. Yogyakarta: Kanisius, 2015.

——- Menjadi Mencintai: Berfilsafat Sehari-Hari. Yogyakarta: Kanisius, 2013.

Ryiandi, Dimas, and Muhammad Ridwan. "Bom Bunuh Diri Di Makassar , Ekstremisme Tetap Subur Meski Pandemi." Jawa Pos. Surabaya, 2021.

Suryarandika, Rizky. "Menebak Motif Di Balik Bom Bunuh Diri Makassar." Harian Aceh Indonesia.

Triguna, I.B.G Yudha. "Kebhinekaan Bangsa Indonesia: Urgensi Dan Relevansinya Dalam Era Revolusi Industri 4.0." Dharmasmrti: Jurnal Ilmu Agama dan Kebudayaan 10, no. 2 (2019): 46-52.

Vanier, Jean. "Komunitas: Tempat Orang Saling Mengikatkan Diri, Memberi Perhatian, Dan Mendukung Dalam Perutusan." In Komunitas Alternatif: Hidup Bersama Menerbarkan Kasih, edited by I. Suharyo. Yogyakarta: Kanisius, 1998.

Wattimena, Deasy Elisabeth, and Kalalo. "Membangun Makna Teologis Gotong Royong Dalam Memperkuat Kebhinekaan." Epigraphe:Jurnal Teologi dan Pelayanan Kristiani 6, no. 1 (2020): 1-15.

Yaniawati, Poppy. "Penelitian Studi Kepustakaan." Penelitian Kepustakaan (Liberary Research), no. April (2020): 15. 